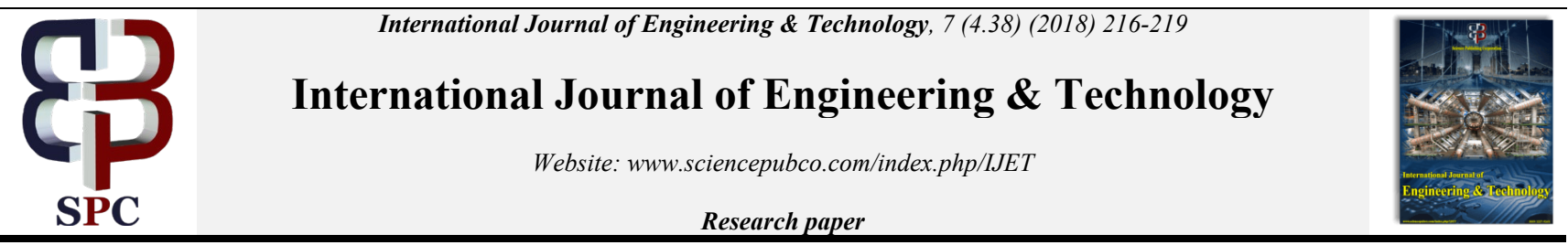

\title{
Insult as a Linguistic and Legal Phenomenon
}

\author{
Olga Nikolaevna Ivanishcheva ${ }^{1}$, Elena Viktorovna Bolgova ${ }^{1}$, Irina Mikhailovna Shadrina ${ }^{1}$, Anna Vladimirovna \\ Gushchina ${ }^{1}$, Sergey Borisovich Nikonov ${ }^{2}$ \\ ${ }^{1}$ Murmansk Arctic State University, Captain Egorov St., 15, Murmansk, 183038, Russia \\ ${ }^{2}$ Saint Petersburg State University, Universitetskaya Embankment, 7/9, Saint Petersburg, 199034, Russia \\ *Corresponding author E-mail: ivanishcheva.o.n@mail.ru
}

\begin{abstract}
In the article, on the material of the texts of linguistic expertise on cases of insult, the main problems and ways of their solution in conducting forensic linguistic expertise of a case of insult in the courtroom are presented. It was stated that when conducting linguistic expertise of conflicting statements, it is not a verbal strategy of achieving the result that matters, but an attack on a person's honor, dignity, and business reputation. The need to include extralinguistic and pragmatic factors in the attention of linguistics expert is emphasized: the focus of insult on a particular person, gestures and the indication of part-of-speech characteristics of the analyzed word.
\end{abstract}

Keywords: Insult; Linguist's competence; Obscene vocabulary.

\section{Introduction}

The relevance of the research topic depends on the need for an indepth study of the interaction of naive and legal consciousness [1, p. $5,2,3]$, while different understanding of insult in everyday and legal consciousness creates difficulties in qualifying a legal rule "insult". The number of legal recourses on insults, especially insult by words, is steadily increasing, and linguistic researchers analyzing journalistic texts, official and personal letters and other products of speech activity from the linguo-expert position often face a certain range of problems in determining a negative (offensive) connotation in a certain word.

Among other issues, an issue of methodology for conducting linguistic expertise in a case of insult is also controversial $[4,5,6,7]$. Despite numerous developments in the field of forensic linguistic expertise on cases of insult, there is no common methodology. Such situation is caused by the disunity of developments conducted by various research teams of expert (state and nonstate) and scientific institutions. The current situation contradicts Art. 11 of Federal Law "On State Forensic Expert Activities in the Russian Federation" No. 73-FZ of May 31, 2001, which states that state forensic expert institutions of the same profile conduct activities for the organization and conduct forensic expertise based on a common scientific-methodical approach to expert practice, professional training and specialization of experts. It is necessary to develop a common generally accepted scientific-methodical approach and the conceptual framework of forensic linguistic expertise in cases of insult [8, p. 393].

The purpose of the article is to present the main problems and ways of their solution in the process of conducting forensic linguistic expertise in a case of insult in the courtroom.

Study materials include the texts of forensic linguistic expertise (15 examinations conducted by the author of the article in 20192015), Resolutions of the Plenum of the Supreme Court of the Russian Federation and other legal documents. The source of the linguistic material includes explanatory dictionaries of the modern Russian language (for example, [9]), the Dictionary of Russian
Colloquial Speech (for example, [10]), the Dictionary of Russian Jargon (for example, [11], the Dictionary of Proverbs and Sayings (for example, [12]) and the Dictionary of the Language of Russian Gestures (for example, [13]).

\section{Methods}

The following research methods were used: definition-component analysis to describe the nuclear elements of a concept of insult; contextual analysis that allows revealing the specificity of the functioning of linguistic means in the text of forensic linguistic expertise in the courtroom; interpretative analysis that establishes the nature of the refraction of the meaning of a concept of insult in linguistic consciousness by using various means of its implementation.

\section{Overview. Question Formulation}

The subject of expertise of materials on cases of insult is linguistic signs of humiliation and indecent form of expression that are relevant for a criminal, civil or administrative offense case $[14,15,16$, $17,18]$. The object of linguistic expertise of materials on cases of insult is a statement as a product of communicative activity, implemented either verbally or in writing, with semantic content and a communicative purpose. The main task in conducting studies of this type is to establish the presence/absence of linguistic signs of humiliation in the text and indecent form of its expression. The tasks of forensic linguistic expertise in a case of insult are reduced to the following points: 1 ) to establish the fact of violation of the rule of legitimacy in communicative interaction: whether a method and a channel of communicative translation of the language code corresponds to the level of the threshold of stylistic justification; 2) to acknowledge an event of reliability of communicative perversion: a conflicting statement contains an opinion or assertion (a legal fact); 3) to establish a legal event of perverse sufficiency: a) a penal provision - an indecent form, a civil law provision - de- 
famatory information (legal criterion); b) to determine the degree of communicative transparency of the verbal portrait of a linguistic personality (linguistic criterion), i.e. the ability of information to influence the social attractiveness of a person who was the target of verbal perversion [19, p. 176].

Kusov has noted three directions in scientific literature on approaches to the conduct of linguistic expertise of conflicting statements:

1) analysis of the author's intentions, which is of general scientific interest in the framework of the speech act theory, since this technique does not bear any legal burden, because, in the final analysis, linguistic expertise is a means of proving in criminal or civil cases under Art. 80 of the Criminal Procedural Code of the Russian Federation or Articles 79-87 of the Civil Procedure Code of the Russian Federation;

2) analysis of techniques and ways that lead to insult, analysis of "the most frequent actions of tactics of causing offense, mockery, and insult";

3) analysis of a complex corpus of ethnic, psychological, moral and ethical components of a concept of "insult", which uses a general conceptual model of insult based on the rules of morality, ethics, human behavior in society; in short, this is the analysis of discrepancy between the behavior of a person and the results of his/her socialization [1, pp. 60-61]

Summing up the latest publications on the development of the topic of "insult and insultingness" in linguistics, Golev has rightly noted that "subjectivism, lack of convincing conclusions, uncertainty and not explicit methods, assessments and arguments indicate inadequate principles and criteria of philological solution of such issues Apparently, this is a new matter that has not been mastered either by courts or expert philologists and requires a certain regulation. Life shows that this most important area of social life requires high professionalism implying specific training. To conduct expert activities, a certain scientific base is required, including the specific interpretation of codified rules, principles, methods, and research vocabulary" [20, p. 29].

The need to revise diagnostic indications of insult in forensic linguistic expertise is emphasized by Podkatilina [8].

\section{Results and Discussion}

Detailed submission guidelines can be found on the journal web pages. All authors are responsible for understanding these guidelines before submitting their manuscript.

Insult is understood as the humiliation of honor and dignity of another person, which is expressed in an indecent form and has three features: 1) the focus on humiliation of honor and dignity; 2) indecent form; 3) deliberate nature of the act. From a semantic point of view, insult contains two components: 1) an addressee of insult receives a negative characteristic; 2) this negative characteristic is expressed in an indecent form. Insult is close to both the act of affirmation and the act of motivation. When insulting someone, a speaker wants to get the addressee's reaction and wants to confirm or improve his/her status. Insult as a speech act is necessarily directed at a particular person - an addressee of insult. Insult can also be expressed in the form of gestures.

When conducting linguistic expertise, an expert should pay attention to the following: 1. It is necessary to distinguish between the invective and noninvective vocabulary, i.e. the one that implies the intention to offend or humiliate an addressee or a third person, and the one that is expressive, but does not imply such intention (see, for example: [21,22]); 2 . The invective vocabulary can be literary and nonliterary (for example, swear words); 3 . The use of invective vocabulary is not always connected with insult; it depends on the presence or absence of intent, on the specific communicative situation.

The authors conducted forensic linguistic expertise in a case of insult for 6 years (2009-2015). The fact of insult in the analyzed texts occurred during court sessions and was addressed to the participants in the court session.

The following questions had to be resolved by the expert: Are the phrases said by M... N.A. (he said "...Eto duristika!" ("Nonsense!") and "esli Vy, uvazhaemaya istitsa s takim privetom" ("If you're so crazy, dear plaintiff"') and twisted his right hand finger at a temple, thus showing that the plaintiff was supposedly mental$l y$ retarded and showed his obvious disrespect for those present) insulting and disrespectful for the participants in the trial? Is the phrase said by Sh... S.V. "Suka" ("Bitch") addressed to K... M.M. insulting? Is the phrase said by O... M.V. "Sobake - sobach'ya smert', a ty zhe u nas sobaka!" ("A dog's death for a dog and you're the dog") addressed to O... I.V. insulting? According to the circumstances of the criminal case, are the words of D... V.M. during the court hearing of civil case No. 000 "Slushai ty, rot zakroi" ("Listen, shut up") and "kozyol" ("asshole") addressed to Sh... K.L. insulting? According to the circumstances of the criminal case, are the words of D... V.V. "Ne delai iz sebya duru!" ("Don't play stupid"), "... Ty chto, tvar'..." ("Hey you, bitch") (he also shouted a phrase: "Dura tupaya!" ("Stupid bitch!")) insulting and disrespectful for participants in the court session?

These and similar cases required the analysis of stylistic affiliation of words that were the object of stylistic expertise, as well as the analysis of their semantic structure. Such analysis emphasizes the use of explanatory dictionaries of the modern Russian language, dictionaries of colloquial speech and jargon. The analysis of the stylistic affiliation of words and phrases, as well as their lexical meaning, led to the following results.

There is no word "duristika" (nonsense) in the dictionaries of the Russian language. According to the context, the word "duristika" (nonsense) is synonymous with the words "dur'" (stupidity), "durost" (foolishness). The word "dur" (stupidity) contains a semantic component "blazh", (caprice), sumasbrodsto" (madness) [9, p. 289], while the word "durost'" (stupidity) contains a semantic component "glupost" (foolishness) [9, p. 289]. The words "dur'" (stupidity), "durost" (foolishness) are colloquial; they have a status label "colloquial" in explanatory dictionaries of the modern Russian language [9, p. 289, 10, p. 162]. The concept "colloquial" means "a characteristic of everyday oral speech used in conversation" [9, p. 1065). The word "duristika" (nonsense) is of a more substandard nature than the synonyms "dur'" (stupidity), "durost" (foolishness). Nevertheless, it seems to be impossible to consider this word as insulting. Consequently, the phrase "Eto duristika!" (Nonsense!) is not an insult.

The expression "s privetom" (crazy) means "a weird, stupid or not exactly normal person" [9, p. 972], "a weirdo with whimsy and deviations in behavior" $[10$, p. 486], it is marked with a status label "colloquial" [9, p. 972), "mocking, colloquial-substandard" $[10$, p. 486]. The term "mocking" means "a person who likes making a mockery of people and ridiculing them" [9, p. 600). The word "mockery" means "an offensive joke about someone or something" [9, p. 600). "Offensive" means "insulting, causing offense; abusive" [9, p. 668). Based on the status label, the phrase "s privetom" (crazy) can be considered an insult.

It should be noted that the use of the phrase "esli Vy, uvazhaemaya istitsa s takim privetom" ("If you're so crazy, dear plaintiff") along with the following gesture: "and twisted his right hand finger at a temple", indicates the strengthening of an offending component. Compare: to twist a finger at a temple - a gesticulating person shows the addressee that, assessing his/her actions, one might think that the addressee went mad [13, p. 107]. Comments on the condition of using a gesture (due to the specific nature of the negative assessment expressed, the gesture is rather rude [13, p. 107]) proves that the phrase "esli Vy, uvazhaemaya istitsa s takim privetom" ("If you're so crazy, dear plaintiff") with the above-mentioned gesture can be considered an insult.

The word "suka" (bitch) is used when talking about a person who causes anger, irritation by her behavior (the addressee is usually a woman) [9, p. 1288], about a woman by emphasizing her gender rudely $[10$, p. 593$]$. The word to be analyzed has the following 
status labels in the dictionary: "rude", "vulgar", "abusive". The term "abusive" means "containing abuse", while "abuse" means "offensive, rude words" [9, p. 94]. The term "vulgar" means "rude, obscene" (about words) [9, p. 165]. The term "rude" means "expressing disrespect, disregard for someone" [9, p. 230].

Thus, the lexical meaning of the word "suka" (bitch) and its stylistic coloring as a rude, vulgar and abusive word do not allow using it when addressing a person; this word offends his/her honor and dignity, as it contains a sharply negative assessment, which means that the phrase "suka" (bitch) is an insult.

The phrase "Sobake - sobach'ya smert', a ty zhe u nas sobaka!" ("A dog's death for a dog and you're the dog") contains a saying "sobake - sobach 'ya smert'" (a dog's death for a dog). This saying is used when "someone talks about the shameful death of a bad (in the speaker's opinion) person" [12, p. 310]. The interpretation of the meaning of the saying implies considering an addressee of the utterance as "a mean person". "Mean" means bad, detestable (about the quality of something); endowed with negative moral qualities; reprehensible, immoral $[9$, p. 289]. The lexical meaning of the word "mean", which is included in the semantic structure of the saying, determines the offensive nature of the expression "sobake - sobach'ya smert", (A dog's death for a dog). The direct indication of the addressee of the utterance in the context of the expression ("Sobake - sobach'ya smert', a ty zhe u nas sobaka!" ("A dog's death for a dog and you're the dog")) proves that the phrase addressed to O...I.V. is insulting.

The phrase "Sobake - sobach'ya smert', a ty zhe u nas sobaka!" ("A dog's death for a dog and you're the dog") also contains a word "sobaka" ( $\operatorname{dog})$ used as a predicate (ty zhe u nas sobaka (and you're the dog)). The word "sobaka" (dog) means "a malicious, cruel, rude person" [9, p. 1224], it is used as a swear word, has a status label "swear, colloquial-substandard" [10, p. 570]. Consequently, the use of the word "sobaka" (dog) in a certain context is offensive, rude and abusive.

In the phrase "ty zhe u nas sobaka" (and you're the dog) the word "sobaka" (dog) is used as a predicate, which means attributing a feature to the addressee of the utterance ("ty" (you)). Consequently, an insult "sobaka" (dog) in this context refers to O... I.V. In the dictionary, the word "kozyol" (asshole) has the following status labels: "swear" [9, p. 437], "rude, colloquial-substandard, contemptuous, slang" [10, p. 437], and it means "a person who irritates with his/her persistent stupidity" [9, p. 437]; "a man who irritates with his stubbornness, stupidity, needlessness"; "gross insult to a man" [10, pp. 262-263]. Thus, the stylistic coloring of the word "kozyol" (asshole) as swear, rude, contemptuous is inappropriate to use when addressing a person; it expresses disrespect, offends his dignity. Besides, the word "kozyol" (asshole) means "gross insult to a man" [10, p. 263]. Thus, the lexical meaning of the word "kozyol" (asshole) does not allow using it when addressing a person (man), expresses disrespect, it offends his dignity.

The term "swear" means "containing abuse". "Abuse" means "offensive, rude words", "swearing" [9, p. 94]. The term "rude" means "showing disrespect, disregard for someone" [9, p. 230]. The utterance "Ne delai iz sebya duru" (Don't play stupid) (colloquial-substandard) means as follows: 1 . To speak disparagingly about someone, ascribing stupidity to him/her; 2 . To pretend to be stupid, narrow-minded for a certain purpose [10, p. 159]. This utterance is synonymous with "make a fool of yourself, play the fool, pretend to be a fool - pretend to be stupid, foolish" [9, p. 288]; "pretend to be foolish, pretend not to understand anything" [10, p. 158].

Despite the fact that the word "dura" (stupid) is insulting both in its lexical meaning and in its stylistic use ("dura" (stupid) - 1. a swear word that means "a stupid, foolish woman" [9, p. 288]; a rude colloquially-substandard word meaning "a young girl or a woman who, in the speaker's opinion, behaves improperly"; "stupid, foolish, shallow-minded" [10, p. 158], the utterance "Ne delai iz sebya duru" (Don't play stupid), which contains the word "du$r a "$ (stupid), is not insulting. This is a phraseologized utterance, the lexical meaning of which does not offend the dignity of the addressee. The component of the meaning "to pretend" (to pose for the purpose of misleading, to act insincerely [9, p. 992] does not contain an insulting meaning; it is not insulting and disrespectful of a participant of communication (in this case - to the participants in the court trial). Thus, the phrase "...Ne delai iz sebya duru!" (Don't play stupid!) said by D... V.V. is not insulting and disrespectful of participants of the court trial, in particular - of E... S.A.

Based on the foregoing, the phrase "Dura tupaya!" (Stupid bitch!) is not an insult, as it contains the word "dura" (stupid) (a stupid, foolish woman) and the definition "tupaya" (bitch) strengthens the semantic component already contained in the lexical meaning of the word "dura" (stupid). Besides, in dictionaries the word "dura" (stupid) has a status label "swear, rude", which is also a sign of disrespect and insult when using this word in speech. Thus, the phrase of D... V.V. "Dura tupaya!" (Stupid bitch!) addressed to E... S.A. is insulting and disrespectful of participants of the court trial.

Speaking about the peculiarities of forensic linguistic expertise in a case of insult, Shabanov gives the following recommendations to linguists: "When conducting independent linguistic expertise, the experts should follow a number of recommendations: 1) to fulfill the requirement of a procedural rule (linguistic expertise cannot contain legal qualifications); 2) to take into account the multifunctionality of the language, for example, invective can both offend and express the internal state of the speaker; 3) expertise must show the strategies of verbal perversion by examples, i.e. to determine the techniques of its achievement, show the way the goal of insult was achieved; 4) an expert must correctly determine the subject matter of expertise, i.e. delineate a linguistic part of expertise from the juridical one. When conducting linguistic expertise of conflict statements, this is not a verbal strategy of achieving the result that matters, but an attack on honor, dignity and business reputation of a person" [19, p. 176].

The first question raised by scientists in cases of insult is to what extent a linguist is competent to draw conclusions on this issue (see about this [23, pp. 88-89]). Lawyers often have a simplistic, naive idea of the linguistic essence of a case, while linguists touch upon topics that are not of interest to legal scholars in linguistic research, since they do not affect the correct legal qualification of a legal rule, but give legal qualifying definitions, which is a prerogative of the court (for example, "there are no grounds for the lawsuit", "unfortunately, moral problems are not a prerogative of the court"; "in the text of expertise there is not a single incorrect fact", etc.) [20, p. 32].

The authors' experience in the field of forensic linguistic expertise shows that a question of insult arises primarily in connection with the use of obscene vocabulary and/or vocabulary with substandard stylistic coloring. This fact is within the linguist's competence; therefore, in the authors' opinion, cases of insult may and should be examined by linguists.

The affiliation of a word to a group of obscene vocabulary also raises many questions among specialists. For example, Podkatilina notes that, based on the methodology, it is not clear how the expert should act in the event that the analyzed lexical units are found neither in dictionaries of the modern Russian literary language nor in dictionaries of substandard vocabulary of the Russian language. In such cases, based on expert practice, it is necessary to apply to the Russian National Corpus, but this should be reflected in the methodology of forensic linguistic expertise [8, p. 393].

The second question that arises in the conduct of forensic linguistic expertise in connection with a case of insult is to what extent the extralinguistic situation should be taken into account when analyzing the fact of insult. It seems logical to apply the approach, which takes into account the entire speech act and the situational context. However, when conducting expertise in practice, a linguistics expert does not often obtain the necessary information about the situation with only a copy of the trial transcript. Therefore, a linguist has no opportunity to assess, for example, the intonation pattern of the statement, the expression on the face, ges- 
tures of an offender and an offendee. In the authors' practice, there was only one case when a gesture accompanying the statement was recorded in the trial transcript.

The third question concerns the need to include in the attention of a linguistics expert a factor of focus of insult on a certain person. Insult as a speech act is necessarily directed at a certain person an addressee of insult. Proving this focus is rather a challenge. In the authors' opinion, the part-of-speech characterization of the analyzed word can help in this case: interjection as a part of speech, denoting a reaction to the surrounding reality, does not express such focus, but, for example, deictic words do.

\section{Conclusion}

In this section you should present the conclusion of the paper. Conclusions must focus on the novelty and exceptional results you acquired. Allow a sufficient space in the article for conclusions. Do not repeat the contents of Introduction or the Abstract. Focus on the essential things of your article.

Insult is understood as the humiliation of the honor and dignity of another person, which is expressed in an indecent form and has three features: focus on humiliating honor and dignity, the indecent form and deliberate nature of the act. From a semantic point of view, insult contains two components: an addressee of insult receives a negative characteristic, which is expressed in an indecent form. Insult is close to both the act of affirmation and the act of motivation. When insulting someone, a speaker wants to get the addressee's reaction and wants to confirm or improve his/her status. Insult as a speech act is necessarily directed at a particular person - an addressee of insult. Insult can also be expressed in the form of gestures. When conducting linguistic expertise of conflict statements, this is not a verbal strategy of achieving the result that matters, but an attack on honor, dignity and business reputation of a person. These cases require primarily the analysis of the stylistic affiliation of words that are the object of stylistic expertise, as well as the analysis of their semantic structure. This analysis emphasizes the use of explanatory dictionaries of the modern Russian language, dictionaries of colloquial speech and jargon.

The authors' research has shown that lawyers often have a simplistic, naive idea of the linguistic essence of a case, while linguists touch upon topics in linguistic research that are not of interest to legal scholars. Nevertheless, when analyzing the fact of insult, it is necessary to take into account not only linguistic facts, but also the extralinguistic situation. It seems logical to apply the approach, which takes into account the entire speech act and the situational context. Thus, the research emphasizes the fact that a linguistics expert needs to pay attention to extralinguistic and pragmatic factors - the focus of insult on a particular person, gestures and indication of part-of-speech characteristics of the analyzed word.

\section{References}

[1] Kusov GV (2004), Oskorblenie kak illokutivnyi lingvokulturny kontsept: dis. ... kand. filol. nauk [Insult as an Illocutive Linguocultural Concept (Ph.D. Thesis)]. Krasnodar.

[2] Speranskaya AN (1999), Oskorblenie slovom v obydennom i pravovom soznanii nositelei russkogo yazyka [Insulting with Words in Ordinary and Legal Consciousness of Russian Native Speakers]. Barnaul: ASU Publishing House, Yurislingvistika-1: Problemy i perspektivy, 89-95.

[3] Chernyshova TV (2014), Filologicheskie aspekty russkoi pravovoi kultury (na materiale rechevogo akta oskorbleniya) [Philological Aspects of Russian Legal Culture (Based on the Speech Act of Insult)]. Problemy istorii, filologii, kultury, 3(45), 389-391.

[4] Araeva, LA \& Osadchii MA (2006), Problemy sudebno-lingvisticheskoi ekspertizy v ramkakh del o zashchite chesti i dostoinstva, o klevete oskorblenii [Problems of Forensic Linguistic Expertise within the Framework of Cases of Protection of Honor and Dignity, Libel and Insult]. Rossiiskii yuridicheskii zhurnal, 2, 86-94.

[5] Baranov AN \& Vinogradov VV, Lingvisticheskaya ekspertiza teksta teoreticheskie osnovaniya i praktika: ucheb. posobie [Linguistic Exper- tise of the Text: Theoretical Grounds and Practice: Training Manual] (2nd ed.). Moscow: Flinta, Nauka, 2009.

[6] Ivanenko GS (2016), Oskorblenie kak polidiskursivnyi i polifunktsionalnyi fenomen [Insult as a Polydiscursive and Polyfunctional Phenomenon]. Meteor-Siti, 1, 72-74

[7] Izotova TM, Kuznetsov VO \& Plotnikova AM (2016), Metodika provedeniya sudebnoi lingvisticheskoi ekspertizy po delam ob oskorblenii [Methodology of Forensic Linguistic Expertise in Cases of Insult]. Teoriya i praktika sudebnoi ekspertizy, 1(41), 92-98.

[8] Podkatilina ML (2016), Sudebnaya lingvisticheskaya ekspertiza po delam ob oskorblenii [Forensic Linguistic Expertise in Insult Cases]. Izvestiva Tulskogo gosudarstvennogo universiteta. Ekonomicheskie $i$ yuridicheskie nauki, 3-2, 389-394.

[9] Kuznetsov SA (2000), Bolshoi tolkovyi slovar russkogo yazyka [Big Explanatory Dictionary of the Russian language]. St. Petersburg: Norint.

[10] Khimik VV (2004), Bolshoi slovar russkoi razgovornoi ekspressivnoi rechi [The Big Dictionary of the Russian Colloquial Expressive Speech] St. Petersburg: Norint, 27.

[11] Mokienko VM \& Nikitina TG (2000), Bolshoi slovar russkogo zhargona: 25000 slov. 7000 ustoichivykh sochetanii [Big Dictionary of Russian Jargon: 25,000 Words. 7,000 Fixed Expressions]. St. Petersburg: Norint.

[12] Zhukov VP (2004), Slovar russkikh poslovits i pogovorok [Dictionary of Russian Proverbs and Sayings] (11th ed.). Moscow: Russkii yazyk; Media.

[13] Grigorieva SA, Grigoriev NV \& Kreidlin GE (2001), Slovar yazyka russkikh zhestov [Dictionary of the Language of Russian Gestures]. Moscow: Yazyli russkoi kultury; Vienna: Wiener Slawistiscer Almanach.

[14] Issers O (1999), Svoboda slova: dve storony medali (oskorblenie v zerkale yurisprudentsii i lingvistiki) [Freedom of Speech: Two Sides of the Medal (Insult in the Mirror of Jurisprudence and Linguistics)]. Barnaul: ASU Publishing House, Yurislingvistika-1: Problemy i perspektivy, 108-124.

[15] Gridina TA \& Tretyakova VS (2002), Printsipy lingvokognitivnogo analiza konfliktnogo vyskazyvaniya [Principles of the Linguistic Cognitive Analysis of a Conflicting Utterance]. Barnaul: ASU Publishing House, Yurislingvistika-3: Problemy yurislingvisticheskoi ekspertizy, 55-64.

[16] Gorbanevsky MV (2006), Kak provesti lingvisticheskuyu ekspertizu spornogo teksta? Pamyatka dlya sudei, yuristov SMI, advokatov, prokurorov, sledovatelei, doznavatelei i ekspertov [How to Conduct Linguistic Expertise of a Contentious Text? Memo for Judges, Media Lawyers, Attorneys, Prosecutors, Investigators, Investigating Officers and Experts]. Moscow: Yuridicheskii mir.

[17] Orlova OV (2002), K voprosu o roli kommunikativnogo podkhoda v lingvisticheskoi ekspertize [On the Role of the Communicative Approach in Linguistic Expertise]. Barnaul: ASU Publishing House, Yurislingvistika-3: Problemy yurislingvisticheskoi ekspertizy, 65-71.

[18] Pachina AN (2015), Leksicheskii aspekt ponyatiya "oskorblenie": k voprosu o sredstvakh yazykovogo vyrazheniya oskorbleniya [Lexical Aspect of the Concept "Insult": On the Means of Linguistic Expression of Insult]. In Aktualnye voprosy izucheniya yazyka, literatury i zhurnalistiki: Materialy X Mezhdunarodnoi nauchno-prakticheskoi konferentsi 24-26 noyabrya $2015 \mathrm{~g}$. [Relevant Issues of Studying the Language, Literature and Journalism: Materials of the 10th International Scientific and Practical Conference held on November 24-26, 2015]. Abakan: FSBEU HPE "N.F. Katanov Khakas State University", 142-145.

[19] Shabanov MM (2010), Osobennosti provedeniya sudebnoi lingvisticheskoi ekspertizy po delam ob oskorblenii [Peculiarities of Carrying out Forensic Linguistic Expertise in Insult Cases]. Vestnik Dagestanskogo gosudarstvennogo universiteta. Seriya 2: Obshchestvennye nauki, 2, 175-179.

[20] Golev ND (2002), Aktualnye problemy yurislingvisticheskoi ekspertizy [Acute Problems of Forensic Linguistic Expertise]. Barnaul: ASU Publishing House, Yurislingvistika-3: Problemy yurislingvisticheskoi ekspertizy, 5-13.

[21] Kaplenko VN, Invektivnost otkrytaya i skrytaya [Open and Hidden Invectivity]. Barnaul: ASU Publishing House, Yurislingvistika-3: Problemy yurislingvisticheskoi ekspertizy, 71-76.

[22] Sypchenko SV (2000), O tipakh invektivnykh tekstov kak obekte lingvisticheskoi ekspertizy problema [On the Types of Invective Texts as an Object of Linguistic Expertise]. Barnaul: ASU Publishing House, Yurislingvistika-2: Russkii yazyk $v$ ego estestvennom $i$ yuridicheskom bytii, 213-220.

[23] Brinev KI (2014), Sudebnaya lingvisticheskaya ekspertiza: metodologiya i metodika: monografiya [Forensic Linguistic Expertise: Methodology and Methods: Monograph]. Moscow: Flinta, Nauka. 